\title{
ABSOLUTE POVERTY AND THE DESIRE TO EMANCIPATE COMMUNITIES DRIVING MOBILE COMMUNICATION FOR DEVELOPMENT (M4D) IN AFRICA
}

Nixon Amuomo iD https://orcid.org/0000-0003-0803-411X

School of Computing and Informatics, University of Nairobi, Kenya

\begin{abstract}
In its opening remarks, The Economist declares emphatically that "Paying for a taxi ride using your mobile phone is easier in Nairobi than it is in New York". There is no denying that Information and Communication Technology for Development (ICT4D) and its subset, Mobile Communication for Development (M4D) have contributed to developments in many societies. This is particularly more dominant and prevalent in developing countries than in the developed nations. This paper reviews reasons why ICT4D/M4D is viewed as more suitable for developing nations than for developed countries despite their technological advancements and higher mobile technology penetration. The conclusion from this review suggests that, absolute poverty and the desire to emancipate communities in developing countries are the driving force for innovation in ICT4D/M4D.
\end{abstract}

Keywords: Mobile communication for development (M4D) in Africa, Information and communication technology for development (ICT4D) in Africa, digital divide

\section{INTRODUCTION}

Amobile for Development (M4D) is an iteration of Information and Communication Technologies for Development (ICT4D). It refers to the use of mobile technologies in global development strategies focusing in the fields of international and socioeconomic development and human rights. M4D relies on the theory that increased access to mobile devices acts as an integral cornerstone in the promotion of overall societal development.

There is direct relationship between ICT and poverty reduction. Many African Governments recognized that ICT can be used to meet the goals of their various visions and the Millennium Development Goals (MDG's) on poverty reduction. The African Governments realized the importance of ICT on poverty reduction; hence they have formulated National ICT Policies. With the uptake of mobile for developments (M4D's) and ICT4D's, the dominance and prevalence of innovations, incubations of ideas in developing countries is on the upsurge. As lamented by the Economist, (2015), that paying for a taxi ride using your mobile phone is easier in Nairobi, Kenya than it is in New York is true. Mobile money payment systems are growing steadily in Africa with vast integrations with core banks. This has revolutionized the way Africans do business.

Manuscript first received: 2017/Sep/08. Manuscript accepted: 2017/Nov/21

Address for correspondence: Nixon Amиomo, PhD Candidate, School of Computing and Informatics, Nairobi, Kenya.

E-mail: namuomo@gmail.com 
Once viewed as an item of luxury and privilege, mobile phones and devices have become a near necessity throughout the developed and developing world alike. According to a 2007 United Nations study, over two thirds of the world's mobile phones are owned and utilized within developing countries. With less-developed wired infrastructure and the high cost associated with its modernization and implementation, the adoption of cellular technologies can be attributed to a necessary leapfrogging of traditional telephony and communication technologies. In addition, the unsound and undependable infrastructure of many developing countries does not augur well to mass hardwired ICT adoption. The portability, battery power, and flexibility of mobile technologies are well suited for lifestyles of those residing in the developing world.

Conversely, Information and communication technologies for development (ICT4D) refers to the application of information and communication technologies (ICTs) toward social, economic, and political development, with a particular emphasis on helping poor and marginalized people and communities. It aims to help in bridging the digital divide and providing equitable access to technologies. ICT4D is grounded in the notions of "development", "growth", "progress" and "globalization" and is often interpreted as the use of technology to deliver a greater good. ICT4D draws on theories and frameworks from many disciplines, including sociology, economics, development studies, library and information science, and communication studies.

\section{LITERATURE REVIEW}

To put ICT4D/M4D into context, we first need to understand what really constitutes development when discussing about ICT4D or M4D. Discourses are raging both in academia and mainstream development cycle seeking to distinguish its meaning and contribution to development (WamalaLarsson, Hellstrom \& Scharff, 2015). Wamala-Larsson, Hellstrom and Scharff (2015) define M4D as the use of mobile devices, services and applications, helped by their mobility, to address social, economic and infrastructural challenges in development-deprived societies. The mobile device seems to be the most appropriate vector as it can reach the remotest areas, and it is this mobility and form factors that makes it more pervasive and appealing for development (Wamala-Larsson, Hellstrom \& Scharff, 2015).

But what makes developing countries to have higher propensity for ICT4D/M4D than developed nations? The old adage that necessity is the mother of invention still holds true with regard to ICT4D/ M4D.According to Todaro and Smith (2015), most developing nations score low on human development indices (HDI). The prevalence of high levels of absolute poverty, poor infrastructure and accessibility, lack of economic stimulants such as electricity, capital, banking services and transport is aggravating underdevelopment in areas of health, education, inequality, poor infrastructure, digital divide are some of the factors influencing this direction. Todaro and Smith (2015) add that lack of technological developments is also major concerns. Wamala-Larsson and Svensson (2015), explains at length that digital gap results into information gaps between regions e.g. urban and rural developing nations, putting those with access to information on the know and on better side of the divide (information haves) and those without (information have-nots) on the other. In the developed nations, this has not been a problem due to availability of multiple methods of accessing information. A mobile device form factor, affordability and its all-in-one capabilities as a computer and communications device is seen to fill this void. Mobile devices have enhanced information access, thus emancipating underserved, marginalized and isolated communities, in education, governance and commerce, and brought them 
closer to the global village (Wamala-Larsson and Svensson, 2015). It is for these reasons that ICT4D/ M4D innovations have found a home in most developing nations.

The instability of electricity or the fact that it still under developed is one of the challenges facing developing nations (Lopez \& Krantzberg, 2014 and Tsivor, 2014). Hence, the arrival of ICT4D/ M4D infrastructure in rural settings is seen to bring certain complimentary development with it such as rampart electricity scarcity. Electricity, in the name of ICT4D or M4D, emancipates the local economy in many ways besides powering and charging ICT4D/M4D devices. It is for this reason that M4D devices, with their battery longevity and portability once charged, make them appealing for use as internet and applications access mediums that are deployed using USSD and SMS based.

\section{M4D CONTRIBUTIONS TO PRO POOR GROWTH}

Poverty is widely recognised as multidimensional, encompassing food security, health, education, rights, security and dignity, among other elements. Pro poor growth has been defined as growth that results in significant poverty reduction, thereby benefiting the poor and improving their access to opportunities (e.g. UN 2000, World Bank 2000, OECD 2001).

Others equate pro poor growth with high elasticity of poverty with respect to growth (e.g. Ravallion and Datt, 2002). Ravallion and Chen (2003) also introduce the concept of "mean growth rate of the poor", which seems analytically ambiguous. Pro poor growth is the type of growth that enables the poor to actively participate in economic activity and benefit proportionally more than the nonpoor from overall income increase. This signals a clear departure from the trickle-down development notion of the 1950s and 1960s that meant a gradual top-down flow from the rich to the poor. Klasen $(2001,2)$ similarly defines "pro-poor growth to mean that the poor benefit disproportionately from economic growth.

Mobile for development has been linked to increased social participation in matters of improved health service delivery and livelihoods (Wamala-Larsson, Hellstrom \& Scharff, 2015). This is known as m-health and is defined by World Health Organisation as the provision of health services and information via mobile technologies such as mobile phones and Personal Digital Assistants (PDAs) (WHO, 2012). In developing nations, tropical diseases and HIV/AIDS prevalence are constant development challenges (Crentsil, 2014). In South Africa for example, in a bid to reduce HIV/AIDS prevalence, there is wide use of SMS texts messaging to expand the uptake of HIV testing and followups in treatment (Crentsil, 2014, p108). Thus, mobile devices have become essential tools for reaching out to and tracking patients in developing nations.

Developed countries, have had advanced, efficient and accessible financial services for a long time. Whereas opening bank accounts and moving money is easier due to established banking and payment systems, in developing countries however, many rural folk are disenfranchised. The arrival of mobile money (mobile wallet) heralded a new beginning. For the urban dwellers, it offered an easy and safe mechanism to send money home. To the rural dwellers, it opened the door for money inflows and for business opportunities. There is no longer need to risk sending physical money via messengers, courier or postal package. Another possible reason why Mobile Money thrives better in developing nations is that their rural economies is mostly micro, subsistence and cash-based, i.e. prepaid cash system- while in developed countries plastic money and credit (post-paid) payments thrive more, according to a Gallup/World Bank study (Togan-Egrican, English and Klapper, 2012). 
Lopez and Krantzberg (2014) further assert that between developed nations and developing nations, there are divergent motivating factors for owning a mobile aside being a communication device. In the West, a mobile phone is a personal accessory that reflects the owner's personality and status (Lopez and Krantzberg, 2014). It is a necessity for even school going children. Whereas in developing nations, due to survival priorities, owning a mobile device is a carefully thought out exercise and is sometime driven by the kin employed in the urban. Even so, the mobile device acts as the link between those in the city and their families in the rural areas - it will be shared in the community. Hence when money is transferred, the mobile device becomes the community teller machine (CTD), no different from town-dwellers automated teller machines (ATMs). There are many other developmental successes in the developing nations which have been attributed to ICT4/M4D. These include e-learning and m-learning, and m-agriculture.

On the flipside, despite the successes, there is tension on M4D on one side and data privacy advocates on the other. Crowe (2015) admit that the proliferation of ICT4D/M4D in just about every social sector, and their use in innovating and promoting delivery of essential services, has also opened concerns on the accumulation, use and sharing of personal data. Crowe $(2015, \mathrm{p}$. 154) seems to suggest that some of this information can be used by those collecting it to perpetuate discrimination, and suggests building capacity in local laws to curb this.

Developing world such as Africa has seen African software developers increasingly designing and developing home grown solutions to African problems, many of which have previously been tackled by outsiders. Local context is becoming increasingly vibrant as university students across Africa graduate with computer science and business management degrees; as innovation hubs spring up across the continent meeting a growing, insatiable demand for places to meet, work and network with like-minded problem solvers and entrepreneurs and as investors launch funds that show they're starting to take young African tech start-ups seriously. This activity hasn't escaped big business. Google, IBM, Microsoft, Nokia, Hewlett Packard and Samsung have been opening offices across the continent, snapping up much of the talent in the process.

\section{MOBILE LEAPFROGGING}

Mobile leapfrogging is a concept used in reference to economic growth theories and industrialization. Leapfrogging has more recently been used in the context of sustainable development for developing countries within the world development theories. Technological leapfrogging therefore refers to the acceleration of development through the skipping of low-grade, less efficient, and more costly technologies and industries in favour of the direct adoption of more effective and advanced technologies. As shown figure 1: Global ICT development chart from year 2001 - 2007 ITU World Telecommunication report, the Mobile cellular utilization has surpassed all traditional forms of technologies steady of the years across all geographies in the globe.

In the case of M4D, the trajectory of the rapid mass adoption of mobile technologies can be attributed to the "mobile leapfrog effect", whereby many developing countries have been seen to bypass traditional routes of wired telephony and broadband infrastructure and development, opting instead for the immediate appropriation of wireless cellular and broadband technology.

Mobile ICT platforms and their wide adoption in developing countries serve as an ideal example of leapfrog technology and current practices of leapfrogging within the sustainable development of developing countries. By enabling developing countries to "leapfrog" over legacy technologies of the 
wired telephone and Internet service of the 20th century and embrace the mobile technologies of the 21 st century, opportunities to bridge the Digital divide have been argued to become more prevalent.

\section{THE DIGITAL DIVIDE}

A digital divide is an economic and social inequality with regard to access to, use of, or impact of information and communication technologies (ICT). The divide within countries or continents or between developed and developing world may refer to inequalities between individuals, households, businesses, or geographic areas, usually at different socioeconomic levels or other demographic categories. Figure 2 below illustrates the gapping between the developed and the developing world in terms of house hold internet access between the year 2002 and the year 2017. The divide between differing countries or regions of the world is referred to as the global digital divide, examining this technological gap between developing and developed countries on an international scale as shown in figures 2, 3 and 4 below.

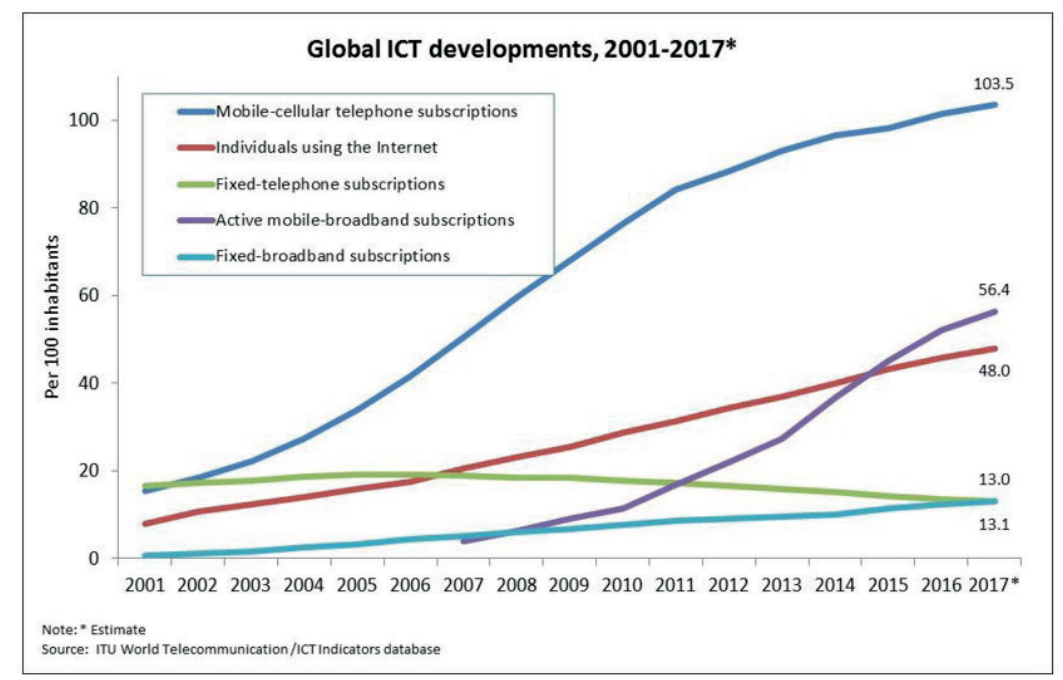

Figure 1. Global ICT developments

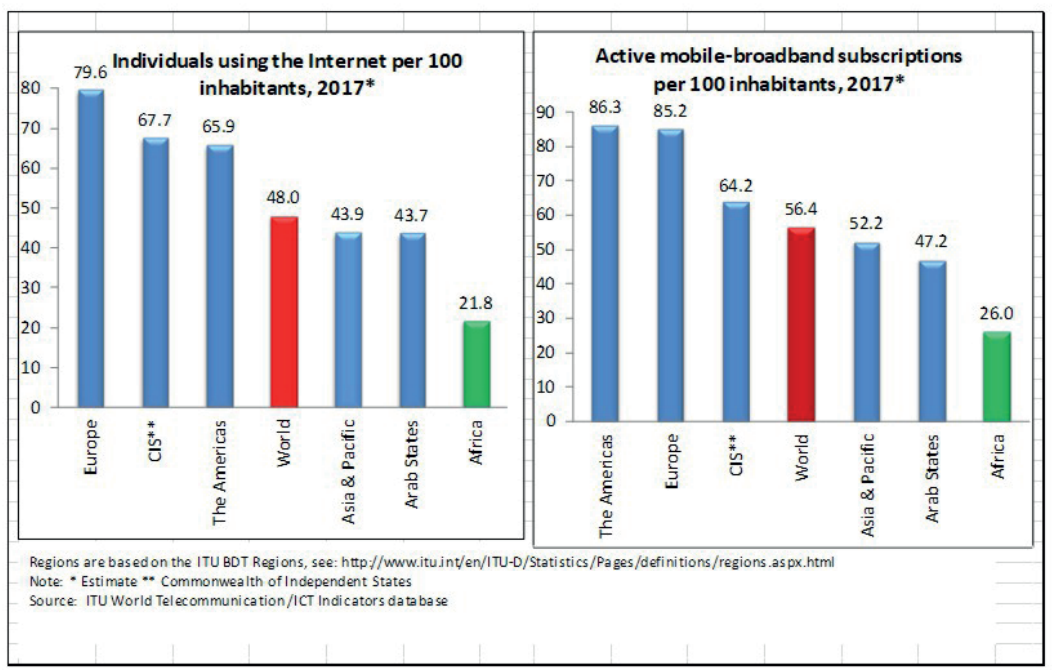

Figure 2. Mobile and internet utilization by African countries 


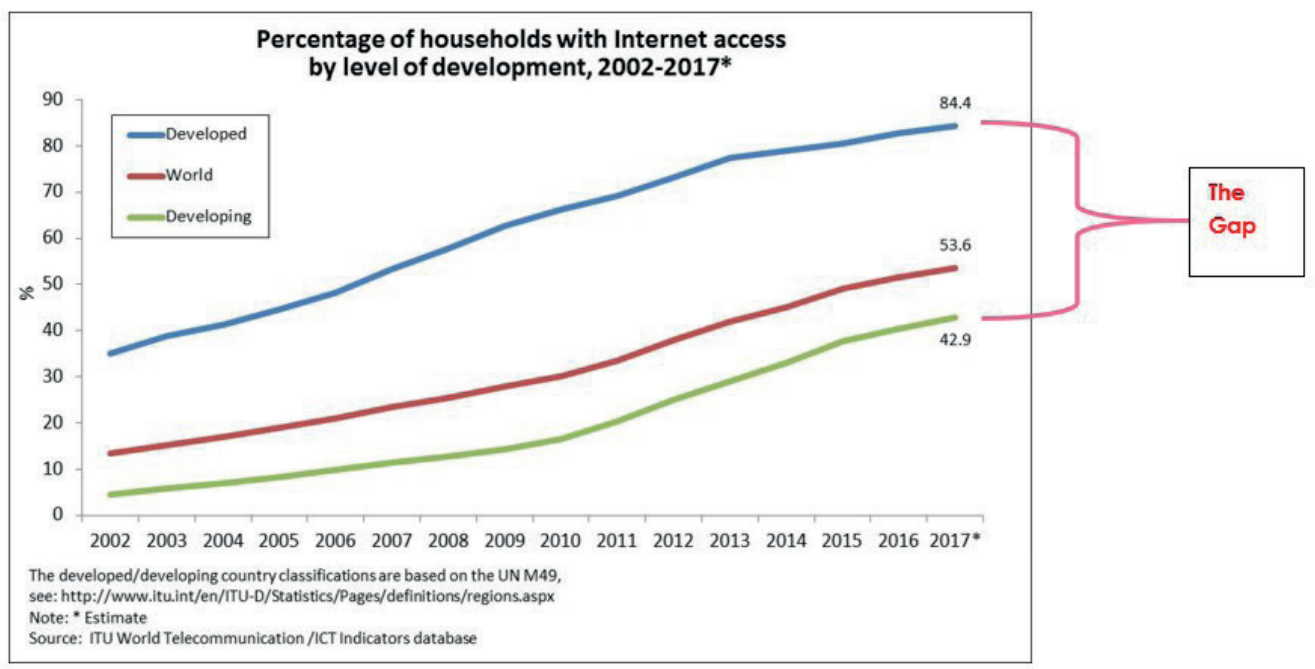

Figure 3. House hold internet access comparisons

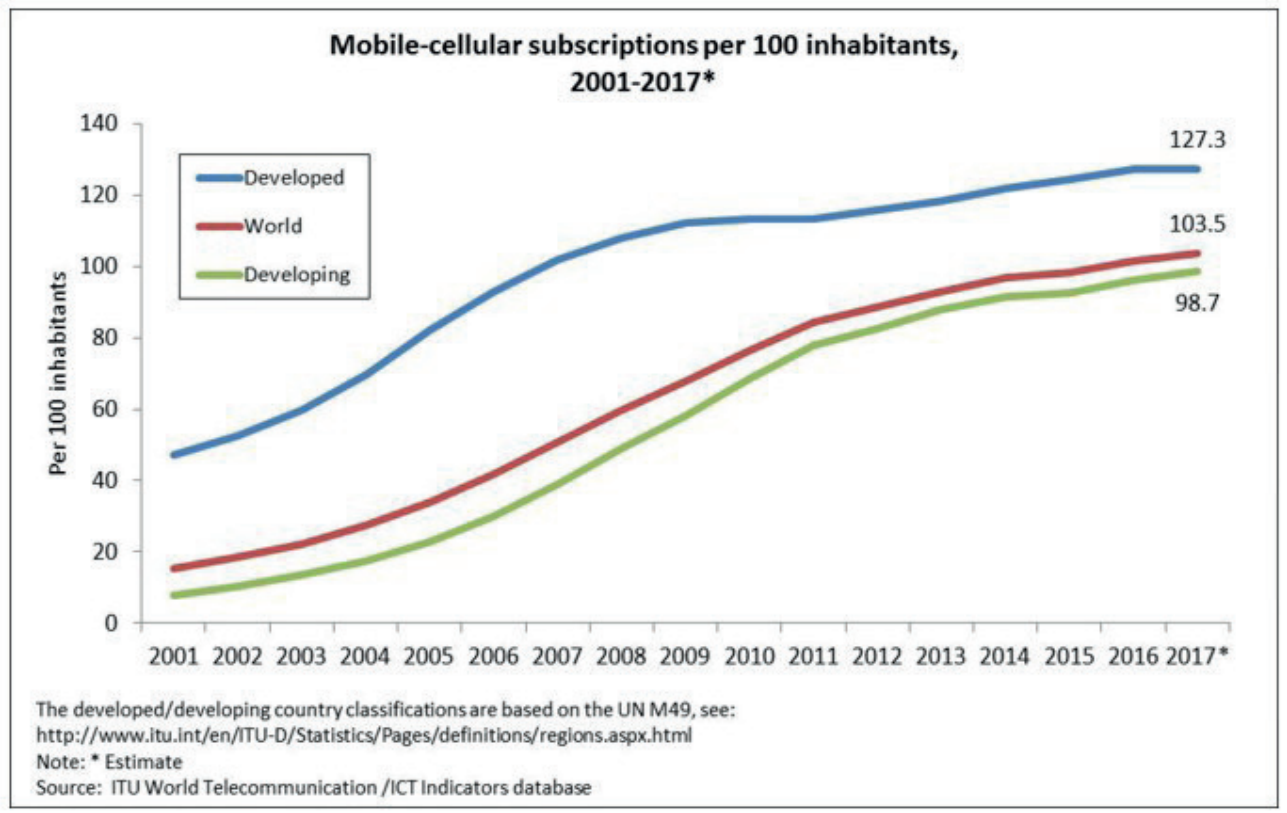

Figure 4. Mobile cellular subscriptions comparisons

\section{CONCLUSION}

The conclusion from this review suggests that, absolute poverty and the desire to emancipate communities in developing countries is the driving force for innovation in ICT4D/M4D. In summarizing, there is no doubt that M4D/ICT4D has permeated and transformed socio-economic lives (what Wamala-Larsson, Hellstrom \& Scharff, 2015 call livelihood) in health, agriculture, banking, education, social lives, information, commerce and so on. It is important that though, bridging the digital divide, it must be sustained to realise further gains in these areas.

The spiral effect is that poverty indicators which have been felt for a long time in African continent, drives the populace to seek ways to create jobs directly and indirectly. Theoretically the concept of looking at ICT ecosystem explains the relationships between innovations and poverty 
driver's reduction on technical, economic and social angles. The diagram in figure 5 below, illustrates the poverty indicators that act as drivers to the ICT innovations in the ecosystem.

\begin{tabular}{|c|c|c|}
\hline $\begin{array}{l}\text { Financial services capabilities } \\
\text { E.g. Mobile banking } \\
\text { applications etc }\end{array}$ & $\begin{array}{l}\text { Establishment of } \\
\text { businesses } \\
-\quad \text { Increased productivity } \\
\text { - } \text { Capital formation } \\
\text { - } \\
\text { Purchase of basic goods } \\
\text { and services }\end{array}$ & \multirow{3}{*}{$\begin{array}{l}\text { Poverty Indicators driving } \\
\text { innovations } \\
\text { - Increased income } \\
\text { - Increased savings } \\
\text { - Improved health status } \\
\text { - } \text { Better shelter } \\
\text { - } \text { Good education } \\
\text { - } \text { Asecent clothing } \\
\text { - Good food and safe water }\end{array}$} \\
\hline $\begin{array}{l}\text { Mobile Systems (M4D and } \\
\text { ICT4D) }\end{array}$ & & \\
\hline $\begin{array}{l}\text { Other support services } \\
\text { E.g. mHealth, m-agriculture } \\
\text { e-learning, mcommerce }\end{array}$ & $\begin{array}{l}\text { - Best management practice } \\
\text { skills } \\
\text { - Enhanced knowledge and } \\
\text { practice of improved } \\
\rightarrow \text { health, education, and } \\
\text { environmental behavior }\end{array}$ & \\
\hline Input & & Ultimate benefit \\
\hline
\end{tabular}

Figure 5. Poverty indicators that act as drivers to the ICT innovations

There comes a time when some of the communities emancipated will start drifting back owing to survival priorities. As the saying goes "Innovate or die" doesn't just apply to the technologies pursued by the ICT4D /M4D community. It applies to the very nature of developing world survival itself.

\section{REFERENCES}

Adera, E. O., Waema, T. M., May, J., Mascarenhas, O. \& Diga, K. (Eds). (2014). ICT Pathways to Poverty Reduction: Empirical evidence from East and Southern Africa. Ottawa: International Development Research Centre. Retrieved from http://idl-bnc.idrc.ca/dspace/bitstream/10625/52420/1/IDL-52420.pdf

Crentsil, P. (2014).Achieving Scale and Sustainability in M-health Solutions for HIV/AIDS in Africa. In: K. E. Skouby \& I. Williams (Ed.). The African Mobile Story (pp. 108). [E-book]. Denmark: River Publishers

Crowe, A. (2015). Privacy and M4D Initiatives. In: C. Wamala-Larsson, C. Scharff \& J. Hellström (Ed.), Mobile Participation: Access, Interaction and Practices (pp.147-164). United Kingdom: Cambridge Scholars Publishing

Economist, The (2015, March 2). Why does Kenya lead the world in mobile money? Retrieved from http:// www.economist.com/blogs/economist-explains/2013/05/economist-explains-18

Fauzel, S., Seetanah, B., Sannassee, R.V. A Dynamic Investigation of Foreign Direct Investment and Poverty Reduction in Mauritius. Retrieved from http://file.scirp.org/pdf/TEL_2016042716363822.pdf

Lopez, A. I., and Krantzberg, G. (2014). Using Mobile Phones for Environmental Protection in Africa: The Equatorial Africa Deposition Network Case Study. In K. E. Skouby \& I. Williams (Ed.). The African Mobile Story (pp. 179-199). [E-book]. Denmark: River Publishers 
Otieno, T. (2016, May 4). Primary school pupils finally get much-awaited laptops. Daily Natin [Online Edition]. Retrieved from http://www.nation.co.ke/counties/Primary-school-pupil-get-laptops/11078723188162-bdg6esz/index.html

Todaro, M. P. and Smith, S. C. (2015). Economic Development. (12nd Ed.). USA: Pearson

Tsivor, K. K. (2014). Sustainable Energy Generation for ICT Development in Sub-Saharan Africa. In: K. E. Skouby \& I. Williams (Ed.). The African Mobile Story (pp. 202). [E-book]. Denmark: River Publishers

Wamala-Larsson, C., Hellstrom, J. \& Scharff, C. (2015). Mobile Participation: An Introduction. In: C. Wamala-Larsson, C. Scharff \& J. Hellström (Ed.). Mobile Participation: Access, Interaction and Practices (pp. 1-15). United Kingdom: Cambridge Scholars Publishing

Wamala-Larsson, C., and Svensson, J. (2015). Participatory Approaches to Development through Mobile Technologies: A Review of the M4D Biennial Conference Proceedings. In: C. Wamala-Larsson, C. Scharff \& J. Hellström (Ed.). Mobile Participation: Access, Interaction and Practices (pp. 17-53). United Kingdom: Cambridge Scholars Publishing

Togan-Egrican, A., English, C., and Klapper, L. (2012, May 1). Credit Cards and Formal Loans Rare in Developing Countries. Retrieved from http://www.gallup.com/poll/154340/credit-cards-formal-loansrare-developing-countries.aspx 